\title{
Effect of an Improvised Furnance on Students Performance in Foundry Technology in Technical Colleges in Rivers State, Nigeria
}

\author{
Ogundu, Isaac (Ph.D) \\ Department of Technical Education \\ Ignatius Ajuru University of Education, Port Harcourt \\ ogunduisaac@yahoo.com, 08064239095 \\ Wordu, Hillary (Ph.D) \\ Faculty of Technical and Science Education, \\ Rivers State University of Science and Technology, Port Harcourt \\ drhillarywordu@yahoo.com, 08037046379
}

\section{Doi:10.5901/mjss.2014.v5n1p649}

\begin{abstract}
The purpose of this research was to determine the effect of an improvised furnace on students' performance in foundry technology in technical colleges in Rivers State. The study adopted research and development incorporating quasiexperimental design. It involved the use of control group, pre-test - post test design. The population of 194 students from four technical colleges in Rivers State were used for the study. The instrument for data collection was made up of Foundry Technology Achievement Test (FTAT) developed by the researcher. The achievement test consists of 50-multiple choice items with four options of $A-D$. The test items were identified and selected from the content of (NABTEB) syllabus on metal work technology. Test re-test method was used to establish the reliability of the instrument; the tests yielded 0.70,073 and 0.72, 0.74 for the first and second tests respectively. Four experts in metal work technology were involved in both face and content validity of the improvised furnace and 200 multiple-choice test items. The results obtained from the test scores were compiled and analyzed using statistical tools such as; percentage, mean, and analysis of covariance (ANCOVA) in answering the research question and testing the hypothesis at 0.05 level of significance. improvised furnace had positive effects on students' performance in foundry (15.32). The difference in performance between those taught using improvised furnace and those taught using conventional teaching aids was found to be significant at 0.05 levels of significance. Based on the findings of the study, the researcher recommended that government, technical college principals and the different agencies should provide fund to procure the materials and component for designing and constructing furnace by the teacher for teaching foundry in technical colleges in Rivers State. Also, constant power supply, generators, accumulators, anvil, steel vessel, pipes and electric blower should be provided and distributed by the ministry of education to the technical colleges for construction of furnace for effective teaching of foundry in Rivers State. The industries, government, non-governmental agencies and private enterprises and communities should provide components, consumable materials necessary for teaching foundry and supply the materials directly to the individual technical colleges in Rivers State.
\end{abstract}

Keywords: Improvisation, Furnaces, Performance, Foundry, Technology and College

\section{Introduction}

Foundry according to Gilchrist (1982) is the production of a desired shape by the introduction of a molten material into a previously prepared cavity, or mold, where it solidifies, is one of the oldest manufacturing processes. Because of the distinct advantages of making it possible to produce intricate shapes of almost unlimited size range, with thin sections when necessary, from any material that can be melted, with the metal being placed where needed for the best resistance to working stresses and having virtually no directional properties, casting remains today one of the most important and basic production processes. The metals most frequently cast are iron, steel, aluminum, brass, bronze, magnesium, and certain zinc alloys. Of these, iron, because of its fluidity, low shrinkage, strength, rigidity, and easy of control is outstanding for its suitability for casting and is used more than all the others.

Foundry or casting is such an important manufacturing process, that is why Blank (1982) stated that many developments in the field have taken place through the ages and particularly in the past 20 years. A number of different types of casting processes have been developed. However, the same basic problems or requirements are encountered 
in each. These common factors are:

a. A mold cavity must be produced. This cavity must be of the desired shape and size, with due allowance for shrinkage of the solidifying metal. Any complexity of shape desired in the finished casting must also exist in the cavity. The material from which the mold is made must be such as to reproduce the detail desired and must be of such a refractory character that it will not be too greatly affected by the molten metal which is to be introduced into the mold.

b. A suitable means of melting the metal to be cast must be available. This melting equipment must provide an adequate temperature and also produce a product of satisfactory quality, usually at low cost.

c. A satisfactory method must be provided for introducing the molten metal into the mold and permitting and assuring the escape of all air or gases in the mold cavity prior to its being filled by the metal, or which may result from the action of the hot metal upon the mold. These conditions must be met in order to have the molten metal completely filled all the details of the cavity and result in a satisfactory casting which is dense and free from defects such as air holes.

d. Adequate provision must be made for the shrinkage which results when most metals solidify and cool. Not only must the mold cavity be slightly larger than the desired product, but there must not be too much restraint to the shrinkage accompanying cooling after solidification, or the casting will be cracked while it is in a state of low strength.

e. It must be possible to remove the casting from the mold. Where the casting is done in molds made from materials such as sand, and the molds are broken up and destroyed after each casting is made, there is no serious difficulty. However, in certain processes where molds of a permanent nature are used, this is a major problem.

f. After the casting is removed from the mold, certain finishing operations must be performed to remove extraneous portions which are attached to the casting as a result of the method of introducing the metal into the desired cavity, or are picked up from the mold through contact of the metal with it.

Much of the development that has taken place in the foundry industry according to Chapman (1994) has been through attempts to solve these six problems with greater economy. There are at present six major types of casting processes.

- Sand casting, In permanent-mold casting, Die casting, In centrifugal casting, Investment casting and Shell casting

Of these processes, sand casting is most widely used and accounts for by far the largest proportion of the total tonnage of castings produced. However, the use of permanent-mold, die, investment, and shell castings has expanded very rapidly in recent years.

For teacher improvised furnace to have the desired effect on student's performance, the teacher must be available and qualify to handle his job. That is why the National Policy on Education (FRN, 2004), stated that crash programs will be mounted to produce a large number of science, commercial, technical and craft teachers to use equipment such as the teacher constructed furnace. Onuebunwa (1991) drew attention to the fact that only 5.5 per cent of the nation's teachers requirements was being met going by a report of a Federal Government Panel set up in 1989, citing the NTBE assessment report of 1990 noted that only 49 out of 551 technical courses taught in Technical Colleges in the country had qualified teachers. Onuebunwa (1991) puts the shortfall at about 45 per cent of the total requirements. These figures may not give an entirely clear picture of the situation but reports from different State Ministries of Education tend to agree with the above picture. The inclusion of Introductory Technology into the Basic school curriculum has further increased the shortfall in Technology Teachers supply vis-à-vis need especially since 6-3-3-4 systems brought in Introductory Technology into the secondary school curriculum. This has led to the employment of under qualified artisans and in some cases pensioners who are ill-equipped to function as teachers of Technology.

The Exodus of qualified Technology Teachers to the industries is another major factor affecting the supply of teachers of technology in our schools and colleges. This migration according to Onuebunwa (1991), has been encouraged by the huge difference between the conditions of service in the teaching services and the industries. To check this obvious trend, Tamuno (1999) urged the appropriate authorities in Nigeria to reverse the imbalance of interest of interest in favour of the teacher in schools. Contributing on this issue, Ake (1998) attributed the phenomenon of brain drain to misrule and corruption rather than insufficient resources. He concluded that it is hoped that our educational problems have little or nothing to do with the demise of our economy or with resource scarcity. He recommended that all should contribute in finding solutions even as individuals in our daily lives. Ake (1998) insisted that teachers are the bases of the education system. Hence, for any educational revolution to succeed, abundance of teachers are needed, he 
therefore blamed brain drain on lack of will to implement well-intentioned policies. Fubara (1998) specifically mentioned the Faculty of Science and Technical Education of the Rivers State University of Science and Technology as being understaffed and under-equipped. He noted that when the Rivers State University of Science and Technology was established in 1980, the Governor gave it a philosophy and mandate as follows: In my brief to the provisional council, it was stated that government was committed to the establishment of a unique and uncommon university that should be structurally and philosophically oriented to solving practical, and in particular, the peculiar and difficult problems of the Niger Delta; and that the University should be intimately dovetailed into our development process-industry, agriculture, commerce, provision of infrastructure, engine for the generation of indigenous technology. It is our wish that the Rivers State University of Science and Technology would unleash the creative and innovative capabilities of our people for the solution of our problems and enhance the quality of life; it should train both the mind and the hand. Fubara (1998) concluded that this mandate has been derailed by the phenomena of brain drain. Since the University cannot produce the right technical personnel it follows that the Technical Colleges must suffer from shortage of qualified teachers to help in improvising furnace for teaching.

Qualified teachers equally involve the ability of the teachers to use Techniques of Instruction, which basically refer to the various methods and procedures which teachers utilize in their efforts to guide the students in their studies. Nwachukwu (2006) maintained that currently the lecture, the tutorial and lesson approaches are among the techniques of instruction predominantly in use. He recommended that teachers could use the following techniques for effective learning response from the students:

1) Discussion (2) Demonstration (3) Simulation (4) Project (5) Team building (6) Laboratory and workshop practices (7) Problems solving (8) Micro teaching techniques (9) Industrial visiting teaching (10) Socio-drama informal role playing (11) Computer assisted instructions (12) Closed circuit television teaching (13) Programmed learning (14) Individualized instructions (15) Independent study.

Balogun (2003) further recommended that the Instructional Systems Design Model could also be used where by scientific models are applied to complex problems in education and training. Peculiar to vocational instructions is individualized instructional package designed to ensure the effective learning and understanding for handicapped group and slow learners. A study of academic aptitude of vocational/technical education students by Bishop (2001) showed that they have considerably greater ability in visual reasoning and manipulative tendencies than other abilities measured. This rather, makes the group to be very successful in skill acquisition. But most teaching methods of our schools, instead of building on these practical manipulative skills, end up in theorizing the subjects ignoring the ancient Chinese proverb that says "You tell me, I forget; show me I remember; involve me, I understand". Technical education being a competencybased education should be taught with a focus on practical skills acquisition generally made possible through constant practice on the job related skills not only on theories. Ernest (2004) maintained that every qualified teacher must be able to move learning gradually from teacher centeredness to learner centeredness. If teachers are actively involved and meaningful strategies applied, the objective will be achieved. This teaching orientation is most suited for subjects requiring practical exercises, for example introductory technology. He defined Introductory Technology as that subject which gives the child greater opportunities for developing manipulative skills. It also enables him function effectively in the society within the limits of his capabilities. Introductory Technology makes the learner get familiar with his environment and orients him properly into work habits towards technology. Invariably, through the use of suitable instructional strategies, the objectives of Introductory Technology can be achieved. Chauhan (2004) agrees that there is abundant evident of discoveries on the effects of various teaching strategies on teaching and learning process. These strategies have relative effectiveness for different subjects and demand that teachers be familiar with these effects. Furthermore, monotonous use of any teaching strategy is likely to have negative consequences to the detriment of learning. Teachers are also unanimous on the use of these strategies in many subjects including Introductory Technology. However, they agree in unison on the usefulness of instructional material in facilitating any teaching strategy adopted by the teacher. These instructional materials are usually in any of these forms: visual, audio and audio-visual types.

Thus, the development of teacher improvised furnace was arrived at following these steps:

(1) The National Business and Technical Examination Board Syllabus in Metal Work was carefully analyzed to determine which aspects of the syllabus that required the use of furnace in teaching. After the content areas have been identified, the specific tasks requiring the furnace were identified such as heat treatment, soldering, forging and foundry.

(2) The next important task was a survey of various source materials and textbooks to determine the actual furnace that could be used. In arriving at suitable furnaces, the type of components that could be available to 
teachers in Rivers State and the functionality of the furnace were also considered.

(3) The teacher constructed furnace is an improvised teaching material that is made up of a steel vessel hardened with carbon - molybdenum of ratio 0.20 per cent, 0.68 per cent respectively. It is lined with bricks and fired with charcoal, using an electric blower connected to a low voltage generator. The furnace was used for: Heat treatment, Soldering, Forging and Foundry and was found to be reliable. The picture of furnace is as seen in the figure 1 below.

Fig 1: Pictures of Improvised Furnace
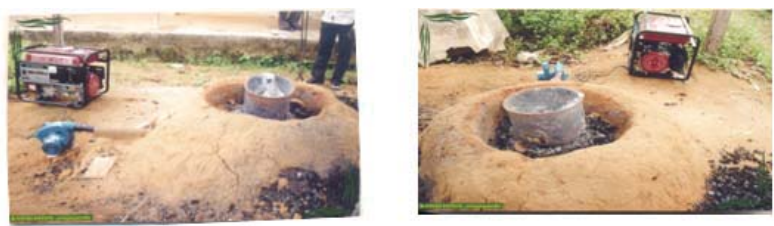

Learning and using improvised furnace in teaching will empower the student during and after training Ezeji (2005) maintained that it is hard to conceived of any other education comparable with technology education that could totally empower the youths. Owing to its various appeals to the three domains of educational objectives, technology education possesses the rudiments to empower the youths' brains, hands, and mind.

\section{Statement of Problem}

Foundry Technology ought to be taught using the same equipment the practitioners are using in the industry because teaching Foundry Technology involves the study of industrial technology. However, Ogundu (2005) observed that there is lack of functional furnace in Rivers State Technical Colleges. Even where imported electric furnace is available, the high voltage electricity needed to power it is not reliable. Lack of functional furnace has possibly led to poor performance of the students in external examination such as National Business and Technical Examination. Candidates performed poorly because, according to the report from Exam Ethics project (2006), they were unable to attempt questions on Blacksmith shop equipment and other equipment for foundry Technology. Lack of functional furnace may have contributed to the students' poor exposure to practical classes. Conventional teaching aids such as drawings, pictures and non functional furnace used in the Technical Colleges for teaching Foundry Technology are only descriptive and cannot be used to teach practicals. For this reason, local construction of a furnace that can function with low voltage generator is imperative. The question then is what effect has this improvised furnace, on students' performance in Foundry Technology?

\section{Research Question}

One research question aided the conduct of the study which stated thus:

1) What is the effect of using improvised furnace, for teaching, on students' performance in foundry operations?

\section{Hypothesis}

$\mathrm{H}_{01}$ : There is no significant difference in the mean performance of technical college students taught foundry, using improvised furnace and those taught with conventional teaching aids.

\section{Methodology}

This study adopted research and development ( $R$ and $D)$ design incorporating quasi-experimental research design. Quasi- experimental design involved the use of pre-test and post-test design with experimental and control groups. This design implies that intact classes were used for the study. This design was necessary because it was not possible for the researcher to randomly sample the students and assign them to groups without disrupting the normal academic programme of the Technical Colleges involved in the study (Akaninwor, 2005C, Ali, 1996). The experimental group were 
treated with improvised furnace while the control group were treated with bellows called conventional teaching aid in this work.

\section{Population and Sample}

The population of the study comprised 194 final year students of the four Technical Colleges offering Metal Work. Final year students were used here because furnace is in their scheme of work. The population of students available in each Technical College was provided by the principal of each school as indicated in the table 1 below:

Table 1: Population and Sample

\begin{tabular}{clcc} 
S/N & \multicolumn{1}{c}{ Location } & Population & Group \\
1 & Ahoada Technical College & 50 & Experimental \\
2 & Ogu Technical College & 34 & Control \\
3 & Port Harcourt Technical College & 62 & Experimental \\
4 & Tombia Technical College & 48 & Control \\
& Total & 194 &
\end{tabular}

There was no sampling as the population of 194 students was used for the study. However, selection of the Technical Colleges into the experimental and control groups was carried out using the simple random sampling techniques.

\section{Instrument for Data Collection}

The instrument for data collection was the Foundry Technology Achievement Test (FTAT) developed by the researcher. Fifty test items were identified and selected from the content of furnace and foundry. The researcher, in constructing FTAT, prepared a table of specification/test blue print to guide the development of the test items.

\section{Results}

\subsection{Research Question 1}

What is the effect of using improvised furnace for teaching foundry operations on student's performance?

Table 2: Mean Scores of Students' Performance on Foundry Operations

\begin{tabular}{lccc}
\hline \multicolumn{1}{c}{ Group } & Pre-Test Mean & Post-test Mean & Mean Gain \\
\hline Experimental & 18.90 & 62.63 & 15.32 \\
Control & 19.73 & 48.23 & \\
\hline
\end{tabular}

The data presented in Table 2 show that students in the experimental group have a pre-test mean score of 18.90, a post test mean score of 62.63 . While students in the control group have a pre-test mean score of 19.73 , a post test mean score of 48.23 , The mean gain was 15.32 . The effect here was that those taught foundry operations using the improvised furnace performed better than those taught with conventional teaching aids.

There is no significant difference in the mean performance of technical college students taught foundry using improvised furnace and those taught using the conventional teaching aids.

Table 3: Analysis of Covariance (ANCOVA) on Foundry

\begin{tabular}{|c|c|c|c|c|c|c|}
\hline Sources of variance & Degree of freedom (df) & Sum of squares & Mean squares & F-cal & F-crit & Remark \\
\hline Between groups & 1 & 3195.59 & 3195.59 & & & \\
\hline Within groups & 191 & 10935.28 & 100.32 & & & \\
\hline Total & 192 & 14130.87 & & 31.85 & 6.333666 & S \\
\hline
\end{tabular}

The data presented in Table 3 show that the F-cal is greater than the F-critical value(F-cal $>F-c r i t)$ at 0.05 level of 
significance. The null hypothesis is then rejected. It therefore means that there is significance difference in the performance of students taught foundry using teacher constructed furnace and students taught with conventional f.

\section{Discussion of Findings}

Intricate ornaments that cannot be forged undergo the process called foundry. Foundry is the production of a desired shape by the introduction of a molten material into a previously prepared cavity, or mold where it solidifies. This process is equally called casting. The performance of students taught foundry using teacher constructed furnace was better at a mean gain of 15.22 than students taught using conventional teaching aids.

The difference in performance between those taught using improvised furnace and those taught using conventional teaching aids was found to be significance at 0.05 levels of significance.

Prosser's (1949) pointed out that the school workshop, laboratories and the total environment where vocational education is given must be adequately equipped to reflect the actual working environment. The theories of vocational education stated by Prosser's tells us that the actual working environment should be equipped to expose the students to the use of the Metal Work materials, tools and components for making furnace that will lead students to the acquisition of relevant knowledge and skills. The higher performance agrees with the result of a study on academic aptitude of vocational carried out by Bishop (2001) where he stated that students have greater ability in visual reasoning and manipulative tendencies than other abilities measured. This rather, makes the experimental group to be very successful in skill acquisition. But conventional teaching aids, instead of building on these practical manipulative skills, end up in theorizing the subjects.

\section{Conclusions}

The purpose of this research was to determine the performance of students in foundry taught with improvised furnace. The study revealed that there was significant difference in the mean performances of students taught foundry, using improvised furnace and those taught using conventional teaching aids. The difference in performance between those taught using improvised furnace and those taught using conventional teaching aids was found to be significant at 0.05 level of significance.

\section{Recommendations}

Based on the findings of the study, the following recommendations were made:

(1) Government, Technical College principals and the different agencies should provide fund to procure the materials and component for designing and developing furnace for teaching foundry in the Technical Colleges in Rivers State.

(2) Constant power supply, generators, anvil, steel vessel, pipes and electric blower should be provided and distributed by the Ministry of Education to the Technical Colleges for construction of furnace for effective teaching of foundry in Rivers State.

(3) Government, Technical College principals and non-governmental agencies should provide fund to procure the materials and components for improvised furnace for teaching foundry to enable students acquire the necessary skills for the world of work.

\section{References}

Ake, C. (1998). Quality Education in a Dwindling Economy. Education and National Development in Nigeria. Ugheli: Eddy-Joe Pub. Nig. Akaninwor, G. I. K. (2005C). Educational Technology (Theory and Practice).Port Harcourt: Wilson Publishing Co.

Ali, A. (1996) Fundamentals of Research in Education. Awka: Meks Publishers (Nig).

Balogun, D. A. (2003). The Use of Audio-visual Materials in Geography Teaching in Post Primary Schools in Nigeria. West African Journal of Education. Lagos: Macmilan Press. 16 (1); 65-70

Bamisaiye, R. (1990). Sociological Foundation of Nigeria Education. (An Introduction), Ibadan: AMD Publisher.

Bishop. G. (2001). New Media in Higher Education and Department of an Audiovisual Instruction. Washington D.C. The Free Press.

Chapman, W.A.J.(1994). Workshop technology part 1. Britain: Athenaeum Press Limited.

Chauhan, S. C. (2004). Advanced Educational Psychology. New Delhi: Vikas Publishers.

Ernest, C. (2004). Using Television in the Primary Schools. London: Routledge Publishers. 
Exam Ethics project (2006) How to Excel in Exams. Lagos: Ethics Project Ltd

Ezeji S. C. O. A. (2005) Empowering the Nigeria youths through Effective Technology Education: Some policy imperative. A lead paper presented at 18th Annual National Conference. Rivers State: Nigerian Association of Teachers of Technology (NATT).

Ezewu, Z. E (1992). Teacher Education in Nigeria in the Year 2000". Perspective on Teacher Education in Nigeria. Lagos: Association for Promotion of Quality Education in Nigeria

Federal Republic of Nigeria (2004) National policy on education. Lagos: Nigerian Educational Research and Development council (NERDC).

Fubara, D. M. J. (2004). Education Role and Policy Priorities for Rivers State And Oil Mineral Areas Development. Education and National Development in Nigeria. Ugheli: Eddy-Joe Pub. Nig.

Gilchrist, J. D. (1982). Extraction metallurgy. Britain: Wheaton \& Co Ltd

Harold, S. (2002). Good Schools, Effective Schools. London: Judgment and their Histories Cases Publishers.

ILO \& UNESCO (2002). Technical and Vocational Education and Training for the Twenty-First Century: UNESCO \& ILO Recommendations. Paris: UNESCO.

Momoh, G. D. (2005). School Headship: Managerial Challenges Kaduna: Kaduna Polytechnics.

National Business and Technical Examination Board (2007-2008). Grade Distribution Sheet. Benin-City: N.A.B.T.E.B Office.

Nwachukwu C.E. (2006). Designing Appropriate Methodology in Vocational and Technical Education for Nigeria. Nsukka: University Trust Publishers.

Ogundu, I. (2005). Factors Affecting Effective Workshop Operations in Technical Colleges in Rivers State. Unpublished M.Ed Thesis. Rivers State University of Science and Technology, Port Harcourt.

Ogurant, O. (1998). Educational Technology. Ibadan. University of Ibadan, Heinemann.

Okujagu, (1992). Context and Content of Teacher Education in the Twenty- First Century Nigeria. Perspectives on Teacher Education in Nigeria. Association for Promotion of Quality Education in Nigeria

Onaga, P. O. (2000). Instructional Materials Utilization Strategies for the Study of Introductory Technology in Nsukka L.G.A.. Vocational Technical Education and Technological Growth. Nsukka: Nigeria Vocational Journal Association (NVA). 2 (1); 15 - 20.

Onuebunwa, S. E. (1999). Improving Teacher Quality and Quantity for Effective Technology Education: Some Basic Issues. Institute Journal for Educational Research and Development (IJERD) Rivers State University of Science and Technology Port Harcourt.1(1); 60-63

Tamuno, T. M. (1999). Education in Nigeria: Its Challenges and Its Promises Ugheli: Eddy-Joe Pub. Nig.

Uwadiae, S. A. (1992 9th - 13th August). Copying with the Challenges of Technology on the pursuit of excellence in Vocational Technical Education. Paper Presented at Alvanna International Conferences on Educational Studies and Research; Owerri.

Wonkwo, S. W. (1992). Efficient Programme of Teacher Education in Nigeria: A case for the 21st Century Nigerian Teacher. Perspective on Teacher Education in Nigeria: Association for Promotion of Quality Education in Nigeria 
